\title{
The Internationalization Process Model Revisited: An Agenda for Future Research
}

\author{
Catherine Welch ${ }^{1} \cdot$ Niina Nummela ${ }^{2,4}$. \\ Peter Liesch ${ }^{3}$
}

Published online: 26 October 2016

(C) Springer-Verlag Berlin Heidelberg 2016

\section{Introduction}

Our interest in this editorial is internationalization processes. We see it as axiomatic that time is elemental to process. Hence, we labelled our Focused Issue ABOUT TIME: PUTTING PROCESS BACK INTO FIRM INTERNATIONALIZATION RESEARCH. At the outset, process research is about events and incidents and their sequencing. It asks questions about who did what, where they did it and how, and why they did do the things they did. This is not to say that the events and incidents will have happened in a neat, discrete and non-overlapping order at specific points in time where each event begins and ends within an orderly temporal sequencing. It is also not to say that the events and incidents will have been orchestrated by just one person who can be explicit as to why they did what they did, and how they did it. How and why things happen is messy but this does not mean explanation is not possible. In this issue, we will take up the challenge of theorizing about these complex processes.

As the field of international business (IB) has a dominant model of the internationalization process, we decided that this model should be our focus. The Uppsala internationalization process model remains much cited-and much critiqued. It has also been revised by its original authors, remaining current with these revisions. Its importance to the IB field cannot be understated. It has incited

Catherine Welch

catherine.welch@sydney.edu.au

1 University of Sydney, Sydney, Australia

2 University of Turku, Turku, Finland

3 University of Queensland, Brisbane, Australia

4 University of Tartu, Tartu, Estonia 
extended debate in our field, a debate which most recently has spawned the research stream of international entrepreneurship (IE). Our arguments in this paper are a contrast to the received view about the model's shortcomings, and provide an alternative interpretation. From a process perspective, it is not the original model nor its more recent formulations that are problematic. Rather, open to critique is the reception the model has received.

The Uppsala model is an explanation not of internationalization but of internationalization process. Yet rarely have those who have written about it paused to consider the implications of this differentiation. This is our objective in this paper. We provide a reading of the model that teases out its process elements and their origins, arguing that such a reading opens up new questions and new approaches for future inquiry. Our position is that our field is yet to fully understand and explore the potential of the model. Hence, we do not agree with those who seem to assume that the model has been superseded because it can no longer explain internationalization processes in today's fast-paced, interconnected world in which time has been compressed and information is only a keystroke away. It also means we disagree with those who dismiss the model as 'superannuated', to quote the opinion of a journal editor communicated to us recently. Rather, the model-as a process theory-represents a challenge to current assumptions and research practices in our field. Our field is not well-practiced at challenging prevailing assumptions, nor is it practiced at making assumptions explicit. Yet challenging assumptions makes a theoretical contribution interesting (Alvesson and Sandberg 2011). Our aim with this paper is to encourage readers to query their current assumptions about the internationalization process model, allowing a new generation of research to revitalize inquiry into internationalizing firms.

\section{Introducing the Model}

Researchers interested in the internationalization process of a firm typically regard the seminal work as being the model which Jan Johanson and Jan-Erik Vahlne, who had both completed their research training at Uppsala University, published in the Journal of International Business Studies (JIBS) in 1977. Johanson and Vahlne have also written a number of articles in which they extend the discussion on the key elements and mechanisms of the model (Johanson and Vahlne 1990, 2003a, b, 2006) and an article with a revised version of the model (Johanson and Vahlne 2009). However, given that the dynamic nature of the model has remained unchanged, the original model is our focus in this section.

The 1977 model is grounded in the broader research program on international business, led by Professor Sune Carlson, which was launched following the establishment of the Institute of Business Studies at the University of Uppsala in the late 1950s. The 1977 publication was the culmination of a decade of intensive research, the impressive scope of which is not appreciated today (for a summary, see Carlson 1966, 1975). The establishment chain and the role of psychic distance were identified from a database of more than 2000 subsidiaries that the group assembled through comprehensive questionnaires of the population of Swedish multinationals 
in 1964 and 1969-1970 (Hörnell and Vahlne 1972; Hörnell et al. 1972; Vahlne and Wiedersheim-Paul 1973). The model was also informed by Jan Johanson's 1966 licentiate thesis of the special steel industry and his study, co-authored with Wiedersheim-Paul (Johanson and Wiedersheim-Paul 1975, p. 305), of the subsidiaries of four Swedish multinationals that at the time were 'often used as examples and patterns in discussions of international operations'.

As we will discuss in more detail below, the model is commonly interpreted as postulating an incremental internationalization pattern, based on two dimensions: (1) a progressive establishment chain of operation modes, and (2) market selection based on the psychic distance from the home market. Johanson and Vahlne themselves (1990) consider the internationalization pattern as one operationalization of the process postulated in their 1977 theoretical model, and also point out that alternative patterns and operationalizations may exist. In fact, in the 1977 article, Johanson and Vahlne (1977, p. 26) pose another, much more interesting question: 'If internationalization indeed follows the pattern described above, how can we explain it?'.

All theories make assumptions, and in their 1977 paper Johanson and Vahlne are careful to specify many of their assumptions. The most important of these (in our view) is that lack of knowledge about foreign markets and foreign operations 'is an important obstacle to the development of international operations and that the necessary knowledge can be acquired mainly through operations abroad' (1977, p. 23). The uncertainty represented by decision-makers' lack of knowledge was a theme that had already been highlighted by Sune Carlson (1974, p. 56), who explained why it was such an impediment to international business: 'The world is large and complex, and it is only partially known to the decision maker. His horizon is limited-often very limited, indeed. The world is also changing. Old knowledge may rapidly become obsolete; it must be supplemented by new knowledge.' The importance of experiential knowledge — of 'learning by doing' — was identified as the critical source of knowledge in various studies by Carlson's research group (Carlson 1975; Olson 1975), as well as by Johanson and Vahlne's own empirical research. Nonetheless, and interestingly, the 1977 model does not explicitly take into account the negative impacts of experiential knowledge; how it may also increase the decision-maker's lateral rigidity (cf., Luostarinen 1979).

The second fundamental assumption relates to the objective of the firm, namely that it 'strives to increase its long-term profit, which is assumed to be equivalent to growth' (Johanson and Vahlne 1977, p. 27). This is very much in line with the thoughts of Edith Penrose (1959), who also equates growth to increase in profits. The influence of Penrose also can be seen in the way in which Johanson and Vahlne consider firm growth to be a joint result of internal and external conditions: internal conditions determine what firms 'see out there' and how they respond to the opportunities recognized.

The third assumption is that the firm 'is also striving to keep risk-taking at a low level', although risk is considered to be relative so what is considered low may vary depending on the decision-maker and the context, which means that higher risks may be acceptable in some circumstances (Johanson and Vahlne 1977). In fact, their thinking on risk is, to use more current terminology, a balancing act between expected rewards and affordable loss; that is, the decision-maker's subjective 
perception of what he or she estimates can be put at risk and potentially lost as an outcome (Dew et al. 2009). Not surprisingly, in a later paper with Figueira-deLemos, Johanson and Vahlne themselves acknowledge the connection between their understanding of risk and affordable loss (Figueira-de-Lemos et al. 2011). Throughout the evolution of the internationalization process model, internationalization is considered to be a continuous process of risk management through a series of decisions (Johanson and Vahlne 1977).

Following these assumptions, the core argument is developed that 'the state of internationalization affects perceived opportunities and risks which in turn influence commitment decisions and current activities' (Johanson and Vahlne 1977, p. 27). This is, as they say, a 'dynamic model' (Johanson and Vahlne 1977, p. 26), in that the present state of internationalization-knowledge of opportunities and challenges in foreign markets (market knowledge) and the amount and transferability of resources committed to a particular market (market commitment) — is considered to have an impact on subsequent decisions. Moreover, the present state is a product of the firm's past activities in foreign markets and its prior decisions to commit resources to foreign operations. The model posits a self-reinforcing cycle that connects past, present and future. Accordingly, internationalization is not an isolated resource allocation problem, but rather a series of interconnected 'decision situations' representing continual 'adjustments to changing conditions of the firm and its environment' (Johanson and Vahlne 1977, p. 26) - that is, internationalization is a process. This shift from conceiving internationalization as a state to a change process is the basis for the model's contribution to the field. While the process nature of firm internationalization might appear self-evident to today's scholars, it was not at the time (Johanson and Vahlne 2003a).

Johanson and Vahlne (1977) also caution that theirs is a 'partial' model, and they are explicit about its scope. They 'do not deal explicitly with the individual decision-maker' (Johanson and Vahlne 1977, p. 26) or variations in decisionmaking styles (Johanson and Vahlne 1977, p. 23), nor do they consider the conditions that prevail in specific 'decision situations' (Johanson and Vahlne 1977, p. 23). Finally, their model is concerned more with how firms expand their operations within individual markets, rather than expansion to greater numbers of markets (Johanson and Vahlne 1977, p. 23). In light of criticisms of the model, it is also worth noting that Johanson and Vahlne acknowledge that the interaction between market uncertainty and the scale of commitment will vary. While they do argue that due to uncertainty, additional commitments 'will be made in small steps' (Johanson and Vahlne 1977, p. 30), they note that this is not always the case. Specifically, the firm may have considerable resources at its disposal; the market may be highly 'stable and homogeneous'; or the firm may have prior experience in similar markets.

While the key change mechanism posited by the original model-the dynamic interplay between learning and commitment-has remained in the later versions, Johanson and Vahlne have deepened their understanding of it. Three advances in particular have been made. The first is that while the learning-commitment cycle was initially conceived as a 'unilateral' (i.e., firm-only) process in 1977, it has been recast as a 'multilateral' (i.e., network-based) process (Johanson and Vahlne 1990 
and in particular 2009). In their revised version of the model, Johanson and Vahlne (2009) point out that experiential knowledge in internationalization is accumulated and shared. The available relevant knowledge base extends beyond firm boundaries; it is nested in relationships and networks. Furthermore, knowledge is not only transferred between network actors, but exchange in the relationships and networks may also result in the creation of completely new knowledge which is privileged and offers the actors a competitive advantage. This shift to a network-based approach, which received its most complete treatment in the 2009 revision to the model, in fact has been a gradual evolution in thinking, the origins of which can be found in Johanson's (1966) licentiate thesis.

The second development has been to provide a more nuanced view on knowledge. While experiential knowledge remains central to the Uppsala Model, there has been recognition that learning-by-doing can be supplemented by other forms of knowledge acquisition, such as imitative learning from competitors, acquisition of another firm (and hence its knowledge base), or making use of the knowledge of network partners (Forsgren et al. 2015). In particular, while the 1977 model focused on the process of acquiring market knowledge, which is not transferable to other national contexts, firms also acquire 'internationalization knowledge': knowledge about how to manage international operations. Internationalization knowledge is not specific to any particular market and consequently can be 'stored in the firm's routines and programs' (Forsgren et al. 2015, p. 9).

A third insight that has extended the original model is that learning-by-doing drives internationalization not only because it enables the firm to reduce uncertainty, but also because it is the way in which the firm identifies new market opportunities. This was already observed in 1977 (p. 29): 'opportunities will be perceived mainly by those who are working on the market, and such opportunities will also lead to extension of the operations on the market'. However, the importance of opportunity identification was little commented on until Johanson and Vahlne (2006, 2009) returned to it as a theme in later papers. They have emphasized that a firm's 'opportunity horizon' (to use their term from the 1977 paper) is formed by the boundaries of the direct and indirect relationships in its networks. As the firm's network is extended through international operations, so too is its opportunity horizon. This makes internationalization an entrepreneurial process (Schweizer et al. 2008). The argument that opportunities are the key elements of the knowledge base which drive the internationalization process resonates well with recent IE literature, and ensures the continued relevance of the model.

\section{A Process Reading of the Internationalization Process Model}

Mats Forsgren has commented that 'like a novel or a poem, the (internationalization process) model has taken on a life of its own, with each scholar having his own interpretation' (Forsgren in Forsgren and Johanson 2010, p. 283). Indeed, theories are the product of a double-hermeneutic process: they are interpretations of the social world that are themselves subjected to the (re-)interpretations of the scholarly community. In this section, we contribute our own interpretation, providing a 
process reading of the original model. Viewed from this lens, we argue that the model stands up to scrutiny rather better than the standard critiques of it, and that a deeper understanding of the process elements of the model suggests avenues for further research that IB (and, more recently, IE) is yet to explore.

Given that one of our arguments is that temporal context needs to be taken into account in order to understand a phenomenon, we commence our process reading with the context in which the original internationalization process model was developed. As the sociology of science suggests, theories are a product of their time (see e.g., Shapin 1995). The model was developed to explain the findings from the in-depth field studies that Sune Carlson initiated, in response to the observation that even though Sweden was highly dependent on trade and faced a competitive international environment, little was known about the international expansion of Swedish firms (Johanson and Vahlne 2003a). The search for a novel theoretical explanation was triggered in the course of fieldwork when existing theoretical frameworks did not match the accounts that interviewees were supplying. The microeconomic theories that were dominant at the time did not explain the patterns that the researchers were seeing (Johanson 2004), so they searched for other theoretical lenses and resources to inform the development of their own model. Crucially, one of the key reasons as to why existing microeconomic theories were insufficient in explaining the empirical results from their fieldwork is that '[d]evelopment over time was not a problem that could be discussed by means of a theory assuming efficiency in equilibrium' (Johanson in Forsgren and Johanson 2010, pp. 284-285). At that time, alternative perspectives on firm behavior were available, notably (but not limited to) Cyert and March's (1963) behavioral theory of the firm, a key work from the Carnegie School of organization theory. This was to be a decisive intellectual influence on the Uppsala group (Johanson and Vahlne 2003a).

While Johanson and Vahlne's original model, as well as its updates, are widely cited, we assert that it is frequently misunderstood. Two misunderstandings in particular are fundamental to any discussion of the process aspects of the model. Both have been raised by Johanson and Vahlne (e.g., 1990, 2006) themselves, but their commentaries have seemingly not been heeded by the research community. The first misunderstanding consists of the failure to distinguish between the theoretical model and the empirical observations on which it is based. The second misunderstanding flows from the first one: given that the empirical observations are mistaken for the theoretical model, the latter is typically misclassified as a stage rather than process model. This misclassification is even less often recognized than the first (see Welch and Paavilainen-Mäntymäki 2014 for an exception).

\subsection{Misunderstanding No. 1}

Turning to the first misunderstanding, critics and followers of the internationalization process model alike often reduce it to the empirical observations that inspired it: namely, the findings that Swedish firms took an incremental approach to internationalization both in terms of the sequencing of geographical expansioni.e., progressing from psychically close to psychically distant markets-and of 
operation modes - i.e., the 'establishment chain' involving lesser to greater levels of resource commitment. But as Johanson and Vahlne have repeatedly observed (1990, 2006), these empirical patterns do not constitute the internationalization process model; rather, they are the empirical phenomena (i.e., internationalization patterns) that the model seeks to explain (see also Hadjikhani 1997; Meyer and Gelbuda 2006; Petersen and Pedersen 1997). Johanson and Vahlne observed in 2006 that the result of this mistaken identity has been that the core mechanism in the model - the interplay between learning and commitment processes-has not been empirically tested or further developed conceptually.

Underlying this misunderstanding is confusion about what theory and theory testing actually entail. As Johanson and Vahlne (2009) have pointed out, any theory is necessarily a simplification and exceptions will always be found; theories are always partial so they have limited predictive power. We would add that theorizing is not about discovering a universally applicable set of causal relationships, as universalities are unlikely to be uncovered in the social world. Theories cannot be proclaimed obsolete because they do not hold in all situations. Rather than being about universals and accurate predictions, theories are, as the prominent sociologist and methodologist Michael Burawoy (2009, p. 20) has put it, 'cognitive maps through which we apprehend the world'. The more we understand what these maps reveal and what they distort, how they can be extended, challenged and revised, and the assumptions that they both harbor and break, the more useful these maps can be for practical action in the world.

Conflating the empirical and theoretical elements of the Uppsala research has been the main source of criticisms of the model which either do not relate to the model itself, or which oversimplify it. As Welch (2004, p. 140) points out, treating the Uppsala Model as being no more than the establishment chain and psychic distance postulates 'has all the hallmarks of a convenient "straw man"'. More relevant questions are ones which Vahlne and Johanson (2002) considered in a piece written during the hype of the dotcom boom: Given that both firms and their business environment have changed considerably since that time, is the model still valid today? How have the empirical patterns changed as a result of changes in international business conditions? And, to what extent have these changes affected the knowledge-commitment interplay in the model? Does uncertainty due to the lack of market knowledge play the same role today? How have new forms of commitment affected the learning process and the need for market knowledge?

Perhaps the part of the 1977 model which is usually considered the most outdated is the element of market knowledge. Johanson and Vahlne assumed that the incremental nature of the internationalization pattern was mainly due to the lack and difficulty of obtaining market knowledge. In today's digitalized world it is difficult to accept that cost or access to information would be as great a challenge or constraint on internationalization as in the 1970s. In fact, access to knowledge may be one factor explaining the shortened time lag between firm inception and first international operations (e.g., Christensen 1991). However, there is empirical evidence that easy access to market information does not guarantee smooth and successful entry to international markets. On the contrary, it may create the illusion of understanding the customer and/or the market and lead to failure in 
internationalization (Nummela et al. 2016). Just as scholars have observed a "paradox of psychic distance" (O'Grady and Lane 1996), a "paradox of information availability" might be at work. That is, the very richness and ease of access of information in today's digital world may lead to the need for quality, specialized information being overlooked. Moreover, information is not knowledge: while there is a wealth of information at decision-makers' fingertips, it needs to be processed, learnt, absorbed and acted upon.

\subsection{Misunderstanding No. 2}

The second misunderstanding is linked to the first but we will treat it separately and in more detail: it has been little remarked upon and it relates to the process nature of the model. Johanson and Vahlne's theoretical model is typically grouped into the same category as the other 'stage models' of internationalization that were proposed in the 1970s (i.e., the so-called 'I-Models'). Classifying the internationalization process model as a stage model occurred early on and has persisted. For example, it is the basis for the influential, but erroneous, critique of the model by McDougall et al. (1994, p. 475), who allege that, along with other stage theories, it posits that 'firms progress in a relatively orderly manner from local firms with ad hoc exporting to full-fledged MNEs'. However, as Vahlne and Johanson (2002, p. 212) have themselves pointed out, they have 'always resisted' their model being characterized as a stage model. They have solid grounds for doing so. They do not provide a model describing or predicting the temporal sequence of modes that a firm will progress through. Rather, they offer a dynamic mechanism-that of experiential learning - to explain changes in a firm's international commitment.

Given its centrality to our argument, we will delve more deeply into the difference between a stage and a process model. To illustrate a stage model, we can turn to Bilkey and Tesar (1977) which is among the 20 most cited papers in JIBS. Their starting point is that export development occurs in stages. They specify six stages, although they are also careful to point out that there may in fact be more than six. These stages are fixed a priori, not inductively derived, with firms categorized as being in one stage or another on the basis of respondents' survey responses. The researchers then ran an analysis to establish whether export behavior varies from one stage to another, and what were the determinants of the stages. In the 1977 study, they tested three stages only, running a multiple regression analysis for each where the stage was used as the dependent variable. On the basis of this analysis, they were able to isolate the variables that were associated with each of these stages. Thus, planning for export was highly correlated with Stage 3 (exploring the feasibility of exporting) and receipt of an unsolicited order high correlated with Stage 4 (experimental exporting). The result of this study is a descriptive understanding of each stage. At the time, capturing different profiles of exporters was an important theoretical contribution, however it does not (nor was it intended to) constitute a theory about the internationalization process.

The criticism of stage models has escalated in recent years, and not just in IB. Stubbart and Smalley (1999) critique the use of stage models to account for organizational and strategic processes, while entrepreneurship scholars have 
scrutinized the stages of growth models that share many of the same features as stage models of internationalization (Levie and Lichtenstein 2010; Neergaard 2003; Phelps et al. 2007). They raise a common set of concerns about the potential limitations of stage models - at least, in their more simplistic form. First, the models can be deterministic in the sense that the stages (as well as the starting and end points) are pre-specified and assumed to apply uniformly, which does not allow for heterogeneous development paths and the role for individual managerial agency in changing course. Second, there is an underlying linear logic: one stage succeeds another, in a prescribed temporal order. This does not allow for discontinuities, backward movements and the recurrence of earlier stages. Third, the stages often consist of descriptions of different states, with common and static characteristics associated with each stage, typically without capturing the underlying reasons for the transition from one stage to another. Fourth, stage models downplay the role of history, chance and environmental contingencies. Critics of such models therefore conclude that theories should move beyond predetermined categories, allow for greater heterogeneity, explore non-linearity and move from descriptive to causal theorizing (see in particular Stubbart and Smalley 1999; Weick 1995).

The internationalization process model has, we would suggest, endured because it avoids these pitfalls of a stage model. In comparison to a simplified version of a stage model, Johanson and Vahlne propose a model of successive and interlinked commitment decisions, with the decisions about resource allocation and market activities from one time period affecting the decisions made in the next, through the accumulation of knowledge, the reduction of uncertainty and the recognition of new market opportunities. This knowledge-commitment cycle provides the 'engine' for change in the model. While there is temporal dependence in the model, with the past imprinting itself on the future, and prior commitment decisions providing a degree of lock-in (Johanson and Vahlne 2003a, p. 12), the outcome is not pre-determined. The model does not predict what the sequencing of operation modes or market entries will be, even though this is often alleged by critics (e.g., Forsgren 2013). Thus, although 'history matters' in internationalization, the model is not path dependent in the strictest sense (Sydow et al. 2009; Vahlne and Johanson 2013). Rather, a 'corridor effect' (Ronstadt 1988) applies: accumulating experiential knowledge leads to increasing recognition of international opportunities, but also ignorance of opportunities in markets in which no or little knowledge exists (Hurmerinta et al. 2015). While the 1977 paper is titled a model of 'increasing foreign market commitments [our emphasis]', this does not imply that there will not be setbacks, discontinuities and reversals (Johanson and Vahlne 2003a). Rather, 'in the long run, it is likely that the increased knowledge will lead to further commitments' (Johanson in Forsgren and Johanson 2010, p. 301).

\subsection{Process Underpinnings of the 1977 Model}

The 'causal cycle' (Johanson and Vahlne 1990) posited in the model can be traced to a variety of influences and inspirations from organization theories of the firm. Foremost among them, as Johanson and Vahlne (1977, p. 23) state in their introduction, is Cyert and March's (1963) behavioral theory of the firm. Key 
behavioral concepts and assumptions about organizational behavior are used, some more explicitly than others, in particular bounded rationality, uncertainty avoidance, problemistic search and organizational learning. These concepts emphasize that organizations base their decisions on imperfect knowledge under conditions of uncertainty. As well, Penrose's Theory of the Growth of the Firm is also cited in the 1977 paper as the source of the distinction between objective and experiential knowledge. We would in fact argue that the debt to Penrose is more fundamental than this. As Johanson and Vahlne (2003a, p. 8) have explained, they were also influenced by her argument that 'a firm's growth is a result of its ability to use, combine and develop resources'. This resource base is particular to the firm, its history and the experiences and perceptions of its managers - a contrast to the fungible factors of production found in traditional economic theory.

An influence that came towards the end of the model's development, but that was not directly referred to in the paper (although it is cited in Johanson and Vahlne 1990), is Weick's organizing model (1979, but first published in 1969). In this seminal work, Weick shifts the theoretical focus from nouns ('the organization', i.e., objects) to verbs ('organizing', i.e., flows and processes), from unidirectional causality to complex interdependence, and from singular events to causal loops of processes. As Jan Johanson explained in a personal communication (19 March 2013):

We talked about the paper as 'internationalization of the firm' until just before we submitted it to JIBS. There were two different reasons. One was that we wanted to stress the importance of what we called 'current activities', which evidently is some kind of process. We thought that we had to add 'commitment decisions' in order to capture something about the foreign direct investments that all other researchers were interested in but we wanted to emphasize the knowledge development processes. A related reason is that we happened to get in contact with Weick's writings about organizing processes. They were described as causal circles which were very like our view.

Cyert and March, Penrose and a last-minute dash of Weick: this might seem a disparate, even potentially haphazard, assembly of theoretical material. However, when probed further, all these theories have important commonalities which mean that they are not based on incommensurable assumptions (see also the discussion of synergies between Cyert and March and Penrose by Pitelis 2007). First, they all question key assumptions of the neoclassical view of the firm. Instead of the neoclassical assumption of decisions being based on rational calculations, organizational members make decisions on the basis of limited knowledge and often erroneous information-decisions which lead to the heterogeneity of firms' resource combinations. Second, they all emphasize the importance of behaviors that deal with uncertainty and equivocality, notably learning and the use of rules and 'recipes' (Weick 1979). Third, they all eschew simplistic linear models and simplified notions of causality as easily reducible to linear, co-variational relationships between dependent and independent variables. Fourth - and highly 
relevant to our current discussion - they all take seriously the role of process and the importance of history.

From today's vantage point, it could be said that the process elements of the model should perhaps have been drawn out more extensively. However, in the context of the period in which the model was first formulated, the need for theories to account for process was not something that would have required elaboration. Not only were the behavioral and growth theories process-oriented, but so too were other influences on the Uppsala group. Information economics, with its focus on how information is transmitted and circulated, was an important grounding for the group given its central interest in knowledge under conditions of uncertainty (see e.g., Carlson 1974). This enabled the group to shift away from information-a static notion-to its dissemination and diffusion, the accumulation of knowledge and learning processes. The concepts of experience and knowledge are, unlike information, time-dependent - as indeed is the concept of commitment.

The origins of the 1977 internationalization process model are therefore more processual than its reception has been. In the next section, we will show how rediscovering these process elements can form the basis for a renewal of research into the internationalization process model. However, renewal requires not only the posing of new questions, but also the rethinking of inquiry in the form of new approaches and new paradigms. Fortunately, as we will argue, recent trends in process research and in research methodology provide the IB field with a rich foundation for a revitalized research agenda into internationalizing firms.

\section{A Future Research Agenda}

In this section, we suggest what a revitalized research agenda on internationalization processes could look like. Exploring the potential of the internationalization process model entails rethinking paradigmatic assumptions that tend to be taken for granted in IB, pursuing a new set of research questions, and utilizing a greater diversity of research methods and approaches. In the course of this section, we explain how the papers in this focused issue contribute to the research agenda that we outline, providing exemplars - and, we trust, inspiration - for future process-based inquiry.

\subsection{New Paradigms}

Over the course of their research careers, Johanson and Vahlne have come to realize that the implications of their internationalization process model are more farreaching than they initially had appreciated. Grounded in behavioral assumptions, the model can be interpreted as a challenge to neoclassical theories of the firm. The most recent (2009) version of the model now couples a behavioral account of managerial decision-making with a behavioral theory of markets. Accordingly, Vahlne and Johanson (2014, p. 160) characterize their own intellectual journey as being one of 'gradual elimination of assumptions emanating from neoclassical economics'. Table 1 lists these assumptions, contrasting them with the behavioral 'assumption ground' (Alvesson and Sandberg 2011) on which their 
Table 1 Replacing neoclassical with behavioral assumptions

\begin{tabular}{ll}
\hline Neo-classical assumptions about firm/market & Behavioral assumptions about firm/market \\
\hline Rational decision-making & $\begin{array}{c}\text { Boundedly rational decision-making, influenced by } \\
\text { affect }\end{array}$ \\
Complete information & $\begin{array}{l}\text { Uncertainty } \\
\text { Disequilibrium }\end{array}$ \\
Equilibrium & Connected nature of firm \\
Endogenous/exogenous distinction & Market is heterogeneous \\
Market is homogeneous & Firm grows through developing opportunities \\
Firm passively adjusts to exogenous conditions & Exchange/commitment \\
Production/investment &
\end{tabular}

Adapted from Vahlne and Johanson (2013), Vahlne and Johanson (2014)

internationalization process model — as extended in 2009-is based. This paradigmatic shift has broader relevance than to the study of internationalization processes, and could also be applied to other topics in IB. Accordingly, Vahlne and Johanson (2013; see also Vahlne and Ivarsson 2014) have recently been turning their interest to other topics, specifically the globalization processes of MNEs.

As Table 1 demonstrates, the internationalization process model constitutes a paradigmatic shift for IB, which as a field of study is still inclined to take neoclassical assumptions for granted. Neoclassical assumptions still permeate internalization theory, leading Vahlne and Johanson (2013) to reiterate the differences between it and their behavioral model (see also Johanson and Vahlne 1990). A behavioral model should be distinguished from other theoretical possibilities, such as the resource-based view, which have surrendered some but by no means all of the neoclassical assumptions in Table 1 (Nightingale 2008). Even the dynamic capabilities framework, which Vahlne and Johanson (2013) note has many affinities with their own model, still retains a more traditional view on managerial decision-making and on markets than the internationalization process model (see e.g., Augier and Teece 2008).

In the behavioral paradigm (Table 1), process is embedded, rather than assumed away as in the neoclassical paradigm. In the behavioral paradigm, managerial decisions are 'history dependent' (Vahlne and Johanson 2013; see also Levitt and March 1988). History matters due to the prior resource commitments the firm has made, the current knowledge and experience of the decision-maker, and the web of trust-based exchange relationships that the firm has built up over time. Recasting resource allocation as resource commitment, information as learning/knowledge and transactions as episodes in relationships all contribute to an explanation that embraces time. The firm's context is also dynamic and shifting due to the connected nature of firm activities: the market-as-network does not and cannot ever reach an equilibrium point. At best, to draw on an early insight found in Johanson (1972), networks may provide some stability alongside their dynamic disequilibrium. While this means decision-makers face inherent uncertainty, with limited influence and even knowledge beyond their immediate network ties, it also provides them with 
opportunities, given that their network positions allow them to connect with new actors and develop new market opportunities.

We would argue, then, that this behavioral assumption ground is an appropriate starting point for factoring in time and process. As well as applying these assumptions in empirical studies, it would also be worth future researchers debating the assumptions themselves. We have presented a single set of alternative assumptions in Table 1, but are others possible? Can we advance additional paradigmatic perspectives that are consistent with a process approach? Are there additional research traditions on which internationalization researchers could draw to inform the study of processes? One of the papers in this issue, by Hurmerinta, Paavilainen-Mäntymäki and Hassett, addresses such paradigmatic questions. They offer a hermeneutic paradigm as an alternative to the 'Newtonian' view that underlies current understandings of time and process. They demonstrate how a hermeneutic approach to temporality challenges existing assumptions in internationalization process research, particularly that of a forward progression or movement. They conceive time as subjectively experienced and interpreted: internationalization accordingly becomes a 'socially constructed storyline' that weaves together past, present and future events, based on the memories, expectations, visions and current interactions of those involved.

\subsection{New Questions}

As is well known, Johanson and Vahlne have since returned to their model to draw out elements - notably opportunity development in their 2006 paper, and relationships and networks, already flagged in their 1990 paper - that were alluded to in the model but not developed fully, nor have been explored by others. We suggest that another such element is that of process. We have argued that the original model is process-oriented, but that its reception as a stage model has meant that this aspect of it has been overlooked and even denied. At this point, it is perhaps tempting to pose some counterfactuals: What if the process nature of the model had been emphasized more explicitly in the original 1977 paper? What if the model, rather than the empirical patterns it sought to explain, had been the focus of subsequent research? What if other scholars had enriched the model by returning to its process origins, such as Penrose, rather than their more static inheritors, such as the resource-based view? As Buckley (in this issue) points out, counterfactuals are not mere idle speculation but are useful explanatory tools. In this case, they can allow us to identify possible explanations as to why this alternative, more process-oriented path was not taken by the IB field.

Again we argue that scholarly development is attributable to the intellectual context in which scholars are operating. The IB field, which by the early 1970s had demarcated itself institutionally through a journal as well as a formal association, very soon adopted a preference for rigid hypothesis-testing investigation and for cumulative research programs with a strong legacy from micro-economics. Given these prevailing assumptions and institutional constraints, the pursuit of processoriented research literally became unthinkable. As a result, calls for longitudinal 
research have been repeatedly made, in an almost ritualistic fashion, without being heeded (for a discussion, see Welch and Paavilainen-Mäntymäki 2014).

More recently, the group of researchers who has staked out what they term a new 'field' of international entrepreneurship has provided their own critique of the internationalization process model. Despite all the criticism, a significant number of these studies has concentrated on comparing different venture types (i.e., so-called born global/international new ventures versus so-called traditional firms) rather than actually studying the internationalization processes of these firms (Jones et al. 2011). As a result, serious attempts to create an alternative theory-based process model are rare. One of the welcome exceptions is the model by Jones and Coviello (2005) which conceptualizes internationalization as a time-based process of entrepreneurial behavior. Unfortunately, neither that model, nor the 1977 Uppsala model, has been used as the basis for further theory development concerning the internationalization processes of born globals/international new ventures. Nor, judging from Nummela's review (2015), has this stream of research been any different from the earlier period of internationalization research in its neglect of longitudinal research designs.

We also contend that as a result of this history, considerable research potential remains in exploring the implications of the internationalization process model. Some of these suggestions have been already made by Johanson and Vahlne themselves:

1. How do the conditions of particular decision situations, and the styles of individual decision-makers, affect the knowledge-commitment cycle?

2. How does the knowledge-commitment cycle evolve over time?

3. Under which circumstances does greater market knowledge not lead to greater commitment to foreign operations and markets?

4. The two empirical patterns covered in the Johanson and Wiedersheim-Paul (1975) paper-the establishment chain and the role of psychic distance-are 'possible [empirical] indicators of the model, but [o]ther indicators may also be possible' (Johanson and Vahlne 1990, p. 13). In other words, can other internationalization patterns be detected and can they be explained using the knowledge-commitment cycle?

5. How are firm internationalization processes 'related to surrounding processes, i.e. market or network internationalization, industry internationalization, technical development, concentration as well as deconcentration processes?' (Johanson and Vahlne 1990, p. 22)

6. The 1977 model does not contain arrows within the state and change boxes, nor does the revised 2009 model (Johanson in Forsgren and Johanson 2010). As such, what are the processes linking market knowledge and market commitment, and commitment decisions and current activities?

In exploring internationalization processes, we have an advantage that was not available to the original Uppsala group: there have been considerable advances in understanding how to theorize about process over the past 30 years. Ann Langley, Andrew Pettigrew and Andrew Van de Ven, as well as many other management 
researchers and entrepreneurship scholars, have over this period developed insights into process theorizing (see, e.g., Langley et al. 2013). This new wave of process research in management can be regarded as having commenced with Pettigrew's (1985) formulation of a 'contextualist' approach to research, in which the variability of processes is studied within the variability of their contexts (defined as encompassing both the 'inner' context of the firm and the 'outer' context of the broad socio-political, historical and economic conditions in which it operates). This process stream of research has provided many suggestions as to how we can, as Weick (1979) put it, go about 'think -ing'. Based on this stream of research, we can add some additional questions to stimulate future research into internationalizing:

1. How do internationalization processes intersect-and collide-with other processes occurring with the firm and the network? How do firms deal with the tensions and contradictions that these interdependent but possibly conflicting forces produce?

2. Rather than focusing on the key concepts in the Model (the state and change aspects), what can we learn by studying the dynamic mechanisms involved? Are there other mechanisms beyond the commitment-learning cycle?

3. How can we account for causal complexity in our understanding of the internationalization process?

4. How can we account for both stability and change when explaining how internationalization evolves over time?

5. What can we learn from different vantage points on the evolution of processes, such as studies of micro-processes of internationalization as opposed to studies of internationalization that relate firm processes to broader industry and societal networks and structures?

6. How can we go beyond studying changes in modes and new market entries, to other events and sequences? What happens in between these mode shifts and new entries (see e.g., Benito et al. 2009)?

7. How can we capture the interpreted and subjective nature of processes and temporality (see Middleton et al. 2011)?

However, in order to pursue the full potential of a process agenda, Langley et al. (2013) emphasize the need to go beyond the bounds of traditional research, which is variance rather than process based. This requires shifting from questions about covariational relationships to questions about how and why sequences and events occur the way they do; from linear to complex causality that incorporates feedback loops, interdependence and causal configurations; from temporality being assumed away to temporality being part of the explanation. As Hurmerinta et al. (this issue) argue, process theorizing requires a more sophisticated understanding of time than treating it as a unit to be measured and as a measure against which events are ordered. There is no single approach to studying process: diverse traditions have emerged, linked to a variety of philosophical assumptions (for a review, see Steyaert 2007), thus providing researchers with a broad spectrum of options.

In this issue, Johanson and Kalinic advance a process agenda by posing the question: how can change in the speed of internationalization be explained? As they 
point out, despite growing interest in speed, existing research has not broken free of the assumptions of a simple, linear process taking place at a constant speed. In contrast, the authors provide a conceptual examination of changes in internationalization speed-that is, acceleration and deceleration-over time. Guided by internationalization process theory, they posit that deceleration results from the challenges a firm faces in integrating the new knowledge it acquires; while acceleration is driven by the exploitation of new opportunities. In their conceptualization, internationalization is composed of multiple forms of expansion, taking place at varying speeds and in a non-linear fashion.

\subsection{New Approaches to Inquiry}

Bringing the process aspect of the internationalization process model to the fore does not only allow for new questions to be placed on the agenda: it also provides an opportunity to reflect on our own practices as a scholarly community. Johanson and Vahlne offer not only a model but a mode of inquiry (see Dubois and Araujo 2004 for a similar argument in relation to Jan Johanson's licentiate findings on business relationships). Their model also demonstrates the insights that can be gained through extended, in-depth fieldwork. But doing in-depth field studies is not enough. In order to develop a plausible theory, as researchers we also need a particular approach to inquiry, to avoid being trapped by our theoretical assumptions. We need to be armed with existing theories, but not blinded, nor bound, by them. We need to listen to the surprises we encounter in the field, rather than imposing existing theoretical categories on the fragments of data we are assembling. Then, when our existing theoretical assumptions break down, we need to read widely and beyond the immediacy of our own field, to provide theoretical ballast for an alternative explanation. In 1992, Johanson, together with Forsgren (Forsgren and Johanson 1992, p. xvii) gave credit to Sune Carlson for having instilled in his students this practice of constantly confronting theory with evidence from the field:

When he started the international business research program, Carlson told us that, first and foremost, we had to empirically investigate international business ... Through a painful process we slowly learnt that business facts are not always consistent with business theory. He taught us to believe in facts rather than theoretical assumptions, so we were forced to organize the facts on the basis of new concepts and theories.

While Forsgren and Johanson (1992) call this an inductive approach, from the perspective of more recent methodological scholarship it would be denoted as abductive: the scholar enters the field with a theoretical starting point, but one that is successively modified and even replaced altogether as a result of empirical insights that challenge it (Dubois and Gadde 2002, 2014). In current methodological discussions, abduction is increasingly being seen as the source of novel theoretical insights. Since Carlson's time, new philosophical trends have undermined confidence in our ability as scholars to discover, unproblematically, 'facts' and 'truths' about the world we study. Facts are social artifacts, constructed by those we study and also by ourselves. However, the abductive process is crucial in enabling 
us to question the theoretical lenses through which we view the world and to overcome the limitations of our own assumptions.

Sune Carlson's group used a mixed-method approach to research. Carlson's (1975) review of the IB group's research activities refers to studies based on a wide array of methods, including multiple regression analysis and other statistical methods, and even experiments. Insights from field interviews clearly played a vital role in developing the theoretical model. It was during interviews that Carlson's students began to realize that the received theories they had been taught had limited explanatory value:

My interviews could be called lightly structured open-ended interviews which perhaps most resembled discussions. My questions stemmed from microeconomic theory. The interviewees' knowledge was almost entirely based on their practical experiences of selling special steel internationally. The interviews revealed an enormous gap between our worldviews. The managers obviously thought I was completely ignorant of reality. And I never got answers to my questions. During the interviews, there was tension in the air that the experienced interviewees broke up towards the end by proposing that I should stick to my theories, which probably were fine, but they would continue working as before. Their industry was probably so special that the theories didn't fit. (Johanson 2004, p. 3).

Although in-depth, open-ended interviews clearly were a transformational (if somewhat traumatic) point in the development of the internationalization process model, quantitative research was also useful in establishing the empirical patterns that needed explaining, and to test emerging hypotheses. This judicious combination of qualitative and quantitative research would, again, seem to be of considerable relevance today. However, the experience of the Uppsala program also suggests that the selection of the qualitative and quantitative methods being deployed also needs to be carefully thought through. In terms of quantitative research, the Uppsala experience suggests the need to go beyond comparative statics; that is, measuring states at two or more time periods, without understanding how the change in states has come about (see also Eden 2009). As Johanson has subsequently explained, the Uppsala researchers did consider going down the path of comparative statics, but realized that this would not produce an explanation that would accommodate process: 'Time does not exist in that world, and obviously, therefore, development over time lay outside the theory' (Johanson in Forsgren and Johanson 2010, p. 285). However, quantitative research can (and we are suggesting should) go beyond comparative statics and the use of proxy variables (such as firm age) rather than the study of processes. We would argue that a renewal of quantitative approaches is possible in today's context, given the widespread availability and expanding range of longitudinal techniques.

While it would seem that qualitative research would be able to incorporate process more readily, we caution against assuming that a qualitative study is necessarily process oriented. Much depends on how the qualitative study is conducted. As Paavilainen-Mäntymäki and Welch (2013) have discussed, there are many ways to 'kill' the process in the course of a case study: posing a research question that does not ask about 'how and why', assembling a cross-sectional 
dataset; reducing data analysis to the identification of themes and categories, rather than tracing processes; and not using the process findings when elaborating the theoretical contribution of the study. We add that the current preference for multiple rather single case studies also makes it more likely that when deciding on the tradeoff between depth and breadth, researchers sacrifice the rich detail required for process data and analysis. However, before making this tradeoff (or, as a reviewer, rushing to advise such a tradeoff be made) it is worth recalling that, as Langley et al. (2013, p. 7) emphasize: 'the sample size for a process study is not the number of cases, but the number of temporal observations'. Undertaking a process study therefore requires us to reevaluate some of our established practices and assumptions regarding qualitative research design, as well as turning to methods that have been under-utilized, such as narrative analysis (e.g., Middleton et al. 2011).

In this issue, two papers have taken up the challenge of going beyond conventional research methods. Hutzschenreuter, Kleindienst, Guenther and Hammes investigate the speed of internationalization of new business units (NBUs) of German multinationals by means of event history analysis, with their dataset spanning the time period between 1985 and 2007. The longitudinal nature of their dataset allowed them to track the internationalization of the NBUs over time. They hypothesize that the internationalization speed of NBUs is not just attributable to their direct experiential learning over time, but also the indirect knowledge they may be able to gain from other units in the multinational. While their dataset does not allow them to observe learning directly, they are able to infer support for their hypotheses about the effects of indirect and direct learning on internationalization speed.

The second paper, by Buckley, advocates that IB scholars make greater use of historical research approaches. This is particularly the case for those researchers who investigate how the internationalization of the firm evolves over time. Buckley's paper serves as an essential primer for anyone seeking to use historical approaches. He reviews four historical methods in particular: source criticism, time series analysis, comparative methods and counterfactual analysis. Informed by the most recent scholarship in history, the paper can be seen as an inter-disciplinary bridge, allowing IB scholars to appreciate the contribution that historical approaches can make to the study of internationalization (see also Buckley 2009).

\section{Conclusion}

The reception and history of the internationalization process model says just as much (or more) about us as a field as it does about the model itself. Our process reading has exposed weaknesses and misunderstandings in the way in which the model has been interpreted. While ours is yet another interpretation, we argue that its advantage is that it provides both internationalization and IE research with a promising and revitalized research agenda. A process orientation will require the field to examine and overturn some existing assumptions and practices, but questioning what we take for granted is ultimately how novel theorizing can be 
spawned. That is the challenge-and the opportunity-that we are hoping to encourage with this issue. IB scholars are well-practiced with the location tenet: where international business activities are undertaken is fundamental to the field. The papers in this issue argue for, and demonstrate the benefits of, research on internationalization that is also accompanied by a time tenet. Given it is now forty years since the publication of the original Uppsala Model, we would argue that such a move is long overdue.

Acknowledgments We would like to thank Lawrence Welch for sharing his recollections of the Uppsala group in the 1970s. Catherine Welch would also like to thank Rebecca Piekkari, with whom she developed the abductive framing of the origins of the 1977 internationalization process model. Above all, we are grateful for the feedback on this paper provided by Jan Johanson and Jan-Erik Vahlne, and for Olli Kuivalainen in helping to facilitate this dialogue as part of the review process for the European International Business Academy conference in 2015. This work was supported by the Estonian Research Council's grant PUT 1003.

\section{References}

Alvesson, M., \& Sandberg, J. (2011). Generating research questions through problematization. Academy of Management Review, 36(2), 247-271.

Augier, M., \& Teece, D. J. (2008). Strategy as evolution with design: the foundations of dynamic capabilities and the role of managers in the economic system. Organization Studies, 29(8/9), 1187-1208.

Benito, G.R., Petersen, B., \& Welch, L.S. (2009). Towards more realistic conceptualisations of foreign operation modes. Journal of International Business Studies, 40, 1455-1470.

Bilkey, W. J., \& Tesar, G. (1977). The export behavior of smaller-sized Wisconsin manufacturing SMEs. Journal of International Business Studies, 8(1), 93-97.

Buckley, P. J. (2009). Business history and international business. Business History, 51(3), 307-333.

Burawoy, M. (2009). The extended case method: Four countries, four decades, four great transformations, and one theoretical tradition. Berkeley: University of California Press.

Carlson, S. (1966). International business research. Uppsala: Almquist and Wiksells.

Carlson, S. (1974). International transmission of information and the business firm. The Annals of the American Academy of Political and Social Science, 412(1), 55-63.

Carlson, S. (1975). How foreign is foreign trade? A problem in international business research. Uppsala: Acta Universitatis Upsaliensis, Studia Oeconomiae Negotiorum.

Christensen, P.R. (1991). The small and medium sized exporters squeeze: empirical evidence and model reflections. Entrepreneurship \& Regional Development, 3(1), 49-65.

Cyert, R. M., \& March, J. G. (1963). A behavioral theory of the firm. Englewood Cliffs: Prentice Hall.

Dew, N., Sarasvathy, S. D., Read, S., \& Wiltbank, R. (2009). Affordable loss: behavioral economic aspects of plunge decision. Strategic Entrepreneurship Journal, 3(2), 105-126.

Dubois, A., \& Araujo, L. (2004). Research methods in industrial marketing studies. In H. Håkansson, D. Harrison, \& A. Waluszewski (Eds.), Rethinking marketing: Developing a new understanding of markets (pp. 207-227). Chichester: Wiley.

Dubois, A., \& Gadde, L. E. (2002). Systematic combining: an abductive approach to case research. Journal of Business Research, 55(7), 553-560.

Dubois, A., \& Gadde, L. E. (2014). Systematic combining: a decade later'. Journal of Business Research, 67(6), 1277-1284.

Eden, L. (2009). Letter from the editor-in-chief: time in international business. Journal of International Business Studies, 40(4), 535-538.

Figueira-de-Lemos, F., Johanson, J., \& Vahlne, J.-E. (2011). Risk management in the internationalization process of the firm: a note on the Uppsala model. Journal of World Business, 46(2), 143-153.

Forsgren, M. (2013). Theories of the multinational firm: A multidimensional creature in the global economy. Cheltenham: Edward Elgar. 
Forsgren, M., Holm, U., \& Johanson, J. (2015). Knowledge, networks and power: the Uppsala School of International Business. In U. Holm, J. Johanson, \& M. Forsgren (Eds.), The Uppsala School of International Business (pp. 3-38). Basingstoke: Palgrave Macmillan.

Forsgren, M., \& Johanson, J. (1992). Managing networks in international business. Amsterdam: Gordon and Breach.

Forsgren, M., \& Johanson, J. (2010). A dialogue about the Uppsala model of internationalization. In U. Andersson \& U. Holm (Eds.), Managing the contemporary multinational: The role of headquarters (pp. 283-304). Cheltenham: Edward Elgar.

Hadjikhani, A. (1997). A note on the criticisms against the internationalization process model. Management International Review, 37(2), 43-66.

Hörnell, E., \& Vahlne, J.-E. (1972). The deciding factors in the choice of a subsidiary sales company as the channel for exports. Acta Universitatis Upsaliensis, Studia Oeconomiae Negotiorum No. 6. Stockholm: Almqvist and Wiksell.

Hörnell, E., Vahlne, J.-E., \& Wiedersheim-Paul, F. (1972). Export och utlandsetableringar (Exports and foreign establishments). Stockholm: Almqvist and Wiksell.

Hurmerinta, L., Nummela, N., \& Paavilainen-Mäntymäki, E. (2015). Opening and closing doors: the role of language in international opportunity recognition and exploitation. International Business Review, 25(6), 1082-1094.

Johanson, J. (1966). Svenskt kvalitetsstål på utländska marknader (Swedish special steel in foreign markets), Licentiate thesis. Uppsala: Department of Business Studies, University of Uppsala.

Johanson, J. (Ed.). (1972). Exportstrategiska problem. Stockholm: Askild and Kärnekull.

Johanson, J. (2004). Vignette: theory is not reality. In R. Marschan-Piekkari \& C. Welch (Eds.), Handbook of qualitative research methods for international business (pp. 3-4). Cheltenham: Edward Elgar.

Johanson, J., \& Vahlne, J.-E. (1977). The internationalization process of the firm: a model of knowledge development and increasing foreign market commitment. Journal of International Business Studies, $8(1), 23-32$.

Johanson, J., \& Vahlne, J.-E. (1990). The mechanism of internationalization. International Marketing Review, 7(4), 11-24.

Johanson, J., \& Vahlne, J.-E. (2003a). Building a model of firm internationalization. In A. Blomstermo \& D. Deo Sharma (Eds.), Learning in the internationalization process of firms (pp. 3-15). Cheltenham: Edward Elgar.

Johanson, J., \& Vahlne, J.-E. (2003b). Business relationship learning and commitment in the internationalization process. Journal of International Entrepreneurship, 1(1), 83-101.

Johanson, J., \& Vahlne, J.-E. (2006). Commitment and opportunity development in the internationalization process. Management International Review, 46(2), 1-14.

Johanson, J., \& Vahlne, J.-E. (2009). The Uppsala internationalization process model revisited: from liability of foreignness to liability of outsidership. Journal of International Business Studies, 40(9), 1411-1431.

Johanson, J., \& Wiedersheim-Paul, F. (1975). The internationalisation of the firm: four Swedish cases. Journal of Management Studies, 12(3), 305-322.

Jones, M. V., \& Coviello, N. E. (2005). Internationalization: conceptualising an entrepreneurial process of behavior in time. Journal of International Business Studies, 36(3), 284-303.

Jones, M. V., Coviello, N., \& Tang, Y. K. (2011). International entrepreneurship research (1989-2009): a domain ontology and thematic analysis. Journal of Business Venturing, 26(6), 632-659.

Langley, A., Smallman, C., Tsoukas, H., \& Van de Ven, A. (2013). Process studies of change in organization and management: unveiling temporality, activity, and flow. Academy of Management Journal, 56(1), 1-13.

Levie, J., \& Lichtenstein, B. B. (2010). A terminal assessment of stages theory: introducing a dynamic states approach to entrepreneurship. Entrepreneurship Theory and Practice, 34(2), 317-350.

Levitt, B., \& March, J. G. (1988). Organizational learning. American Review of Sociology, 14, 319-340.

Luostarinen, R. (1979). Internationalization of the Firm. Helsinki: Acta Academiae Oeconomicae Helsingienis, Helsinki School of Economics.

McDougall, P., Shane, S., \& Oviatt, B. (1994). Explaining the formation of international new ventures: the limits of theories from international business research. Journal of Business Venturing, 9(6), 469-487.

Meyer, K. E., \& Gelbuda, M. (2006). Process perspectives in international business research in CEE. Management International Review, 46(2), 143-164. 
Middleton, S., Liesch, P. W., \& Steen, J. (2011). Organizing time: internationalization narratives of executive managers. International Business Review, 20(2), 136-150.

Neergaard, H. (2003). The process of entrepreneurship: a managerial and organizational journey. In C. Steyaert \& D. Hjorth (Eds.), New movements in entrepreneurship (pp. 160-176). Cheltenham: Edwards Elgar.

Nightingale, P. (2008). Meta-paradigm change and the theory of the firm. Industrial and Corporate Change, 17(3), 533-583.

Nummela, N. (2015). Future agenda for research design in international entrepreneurship. In Stephanie A. Fernhaber \& Shameen Prashantham (Eds.), The Routledge companion to international entrepreneurship (pp. 245-255). New York: Routledge.

Nummela, N., Saarenketo, S., \& Loane, S. (2016). The dynamics of failure in rapidly internationalising firms: a case study of Finnish and Irish software companies. International Small Business Journal, 34(1), 51-69.

O'Grady, S., \& Lane, H. W. (1996). The psychic distance paradox. Journal of International Business Studies, 27(2), 309-333.

Olson, H.C. (1975). Studies in export promotion: attempts to evaluate export stimulation measures for Swedish textile and clothing industries. Doctoral thesis, Uppsala University, Disciplinary Domain of Humanities and Social Sciences, Faculty of Social Sciences.

Paavilainen-Mäntymäki, E., \& Welch, C. (2013). How to escape an unprocessual legacy? A viewpoint from international business research. In M. E. Hassett \& E. Paavilainen-Mäntymäki (Eds.), Handbook of longitudinal research methods on organisation and business studies (pp. 229-248). Cheltenham: Edward Elgar Publishing.

Penrose, E. T. (1959). The theory of the growth of the firm. Oxford: Oxford University Press.

Petersen, B., \& Pedersen, T. (1997). Twenty years after: support and critique of the Uppsala internationalisation model. In I. Björkman \& M. Forsgren (Eds.), The nature of the international firm: Nordic contributions to international business research (pp. 117-134). Copenhagen: Handelshojskolens Forlag.

Pettigrew, A. (1985). Contextualist research: a natural way to link theory and pratice. In E. E. Lawler, et al. (Eds.), Doing research that is useful for theory and practice (pp. 222-274). San Francisco: Jossey-Bass.

Phelps, R., Adams, R., \& Bessant, J. (2007). Life cycles of growing organizations: a review with implications for knowledge and learning. International Journal of Management Reviews, 9(1), 1-30.

Pitelis, C. N. (2007). A behavioral resource-based view of the firm: the synergy of Cyert and March (1963) and Penrose (1969). Organization Science, 18(3), 478-490.

Ronstadt, R. (1988). The corridor principle. Journal of Business Venturing, 1(3), 31-40.

Schweizer, R., Vahlne, J.-E., \& Johanson, J. (2008). Internationalization as an entrepreneurial process. Journal of International Entrepreneurship, 8(4), 343-370.

Shapin, S. (1995). Here and everywhere: sociology of scientific knowledge. Annual Review of Sociology, $21,289-321$.

Steyaert, C. (2007). 'Entrepreneuring' as a conceptual attractor? A review of process theories in 20 years of entrepreneurship studies. Entrepreneurship and Regional Development: An International Journal, 19(6), 453-477.

Stubbart, C. I., \& Smalley, R. D. (1999). The deceptive allure of stage models of strategic processes. Journal of Management Inquiry, 8(3), 273-286.

Sydow, J., Schreyögg, G., \& Koch, J. (2009). Organizational path dependence: opening the black box. Academy of Management Review, 34(4), 689-709.

Vahlne, J.-E., \& Ivarsson, I. (2014). The globalization of Swedish MNEs: empirical evidence and theoretical explanations. Journal of International Business Studies, 45(3), 227-247.

Vahlne, J.-E., \& Johanson, J. (2002). New technology, new companies, new business environments and new internationalization processes? In V. Havila, M. Forsgren, \& H. Håkansson (Eds.), Critical perspectives on internationalisation (pp. 209-227). Amsterdam: Pergamon.

Vahlne, J.-E., \& Johanson, J. (2013). The Uppsala Model on evolution of the multinational business enterprise: from internalization to coordination of networks. International Marketing Review, 30(3), 189-210.

Vahlne, J.-E., \& Johanson, J. (2014). Replacing traditional economics with behavioral assumptions in constructing the Uppsala Model: toward a theory on the evolution of the Multinational Business Enterprise (MBE). In J. J. Boddewyn (Ed.) Research in global strategic management, 16 (Multidisciplinary Insights from New AIB Fellows) (pp. 159-176). 
Vahlne, J.-E., \& Wiedersheim-Paul, F. (1973). Ekonomiskt avstånd: Modell och empirisk undersökning (Economic distance: Model and empirical investigation). In E. Hörnell, J.-E. Vahlne, \& F. Wiedersheim-Paul (Eds.), Export och utlandsetableringar (Export and foreign establishments) (pp. 81-159). Uppsala: Almqvist och Wiksell.

Weick, K. E. (1979). The social psychology of organizing (2nd ed.). New York: McGraw-Hill.

Weick, K. E. (1995). What theory is not, theorizing is. Administrative Science Quarterly, 40(3), 385-390.

Welch, L. (2004). International entrepreneurship and internationalization: common threads. In L.-P. Dana (Ed.), Handbook of research on international entrepreneurship (pp. 137-149). Cheltenham: Edward Elgar.

Welch, C., \& Paavilainen-Mäntymäki, E. (2014). Putting process (back) in: research on the internationalization process of the firm. International Journal of Management Reviews, 16(1), 2-23. 